heavy-water reactor; a steam generating heavywater system already being developed at Risley; a high-temperature reactor system which might be developed from the Dragon reactor. Much work is going into the use of plutonium as a reactor fuel, but its commercial use is still distant. Mr. Freeth stressed the need to keep the whole research programme flexible and to be ready to take advantage of any reactor systems developed elsewhere which might appear promising. The pressurized water reactor used in the American merchant vessel Savannah was unlikely to provide an economical system.

\section{National Science Foundation International Science Activities Office}

AN Office of International Science Activities, headed by Dr. Arthur Roe, has been established by the U.S. National Science Foundation. Dr. Roe has been head of the Foundation's Planning Group for Educational and International Activities, the duties of which are now assigned to other Foundation offices. The main duties of the new Office will be: to provide staff and policy guidance on the international aspects of supporting research, science education, exchange of scientific information, and other, related matters; to co-ordinate the Foundation's activities involving new programmes or policies of international scope or significance; to administer Foundation staffs in Tokyo and Paris; and to develop experimental programmes in international science co-operation. In addition, the new Office will aid the Department of State in planning, developing and administering U.S. foreign policy in science and science education.

\section{Radioactivity in Water Supplies}

REGULAR measurements of radiostrontium and radiocæsium in twenty water supplies derived from reservoirs, rivers and wells are made by the Health Physics and Chemistry Division of the Atomic Energy Research Establishment. The results of tests made from 1957 to the end of 1960 (A.E.R.E. Research Group Rep. $R$ 3552) show that the activity in both reservoir and river supplies increased in 1959 when the activity in rain increased, but that tho subsequent rate of fall of activity due to strontium was not so rapid as in rain. It appears that, particularly for reservoir supplies, this is dve to gradual leaching of strontium-90 previously adsorbed by the ground. The part played by adsorption in determining the concentration of radioactive substances in water is also shown in a preliminary survey of the effect of radioactive effluent discharged to the Thames from Harwell (A.E.R.E. Res. Group Rep. $R$ 3555). The principal radioactive constituent of this effluent is cæsium-137, and the amount of this element adsor bed on the river bed is sufficient to reduce significantly the amount of radiocæsium which would otherwise be present in drinking-water derived from the riv эr. In contrast to the behaviour of strontium, the adsorption of radiocasium appears to be almost irreversible.

\section{The National Research Development Corporation of India}

THF soventh annual report and statement of accounts of the National Research Development Corporation of India cover the year ended March 31, 1961, in which 31 inventions were reported for development by 14 research institutes, including 2 from foreign countrios, making a total of 584, of which 350 aro effectively in hand (Pp. 31. Now Dolhi :
National Researeh Development Corporation of India, 1961). Thirteen new patent applications were filed and 15 Indian patents obtained; 39 processes are licensed and in production and 78 licensed but not in production, while 94 have been released to industry, free of royalties, or technical details have been publishod; 234 processes have been dropped or with. drawn. New projects initiated during the year included prototype plants for ' $\mathrm{Hycol} X$ ' activated carbon and the integrated processing of oil seeds; a Corporation unit for aromatic chemicals and Costus root oil at the National Chemical Laboratory, Poona, and a pilot plant for $p$ - and $m$-cymene. Production of carboxymethylcellulose at Bilimora was inaugurated in January 1961, of pine oil at Hoshiarpur in July 1960, and of the Amul baby food plant at Anand in October 1960. Pilot-plant work on the de-ionization of canesugar juice continued, the semi-commercial fluidizedbed unit for textile processing has been erected, installation of the pilot plant for phthalic anhydride completed, and optimum conditions have been determined for first sintering limestone, feldspar and gypsum from Rajasthan in the pilot white-cemont kiln.

\section{Fire Notes}

THE Joint Fire Research Organization has commenced publication of a series of Fire Notes providing guidance to architects and oth9rs who are faced with the problem of producing buildings to meet the fire regulations without using uneconomic methods of construction. The first of these has recently been issued (Fire Note No. 1: Fire-resistance of Floors and Ceilings. By G. I. Bird. Pp. ii +14 . London: H.M.S.O., 1961. 2s. net). The fire-resistance of a floor is assessed in terms of the time for penetration from below by a standard fire, as laid down in British Standard 476 : Part $1: 1953$. Methods of increasing the fire-resistance of wood floors to specified extents by the addition of ceilings of various typos are described. The higher resistances of typical re-inforced and pre-stressed concrete floor structures are quoted, with a note on the repair of such floors after exposure to fire. Finally, advice is given regarding the restriction of extent and protection of openings in fire-resistant ceilings required for light fittings, ventilation ducts and other services.

\section{Science as an Aid to Understanding}

Is his Thomas Cawthron Memorial Lecture, "Science as an Aid to Understanding", and now published as a booklet (Pp. 19. Nelson: Cawthron Institute, 1961), Viscount Cobham, Governor-General of New Zealand, questioned as too sweeping the assertion that those of the traditional culture failed to understand the scientific revolution of the twentieth century which is creating an industrial society of electronics, atomic energy and automation. $\mathrm{He}$ thought that the present system of education did not tend to produce all-rounders, and that the tendency towards greater specialization made it more and more difficult for the schools to provide the balanced training that was needed-well-disciplined scholars in the liberal tradition who had also received a reasonably good scientific training. Emphasizing that the average pupil needed discipline if he were to become a good and responsible citizen, Viscount Cobham thought it was sheer waste of first-class material to hold the most gifted back to the pace of the average, but he pointed out that few of the world's great problems were capable of solution through the intellect alone : the element of intuition or imagination. 